\title{
Teoretyczne nasycenie w badaniach wykorzystujących procedury metodologii teorii ugruntowanej - z doświadczeń młodego badacza
}

\begin{abstract}
STRESZCZENIE
W obszarze badań zorientowanych jakościowo pojęcie nasycenia jest ściśle związane z metodologią teorii ugruntowanej. Do jej metodologicznych procedur należy teoretyczne nasycenie kategorii. Jest to zasadnicze kryterium, sygnalizujące zakończenie zbierania grup porównawczych (Konecki, 2000). Metodologia teorii ugruntowanej dostarcza jasnych instrukcji postępowania, jednak podczas prowadzenia badań pojawia się wiele dylematów na drodze zbierania danych empirycznych oraz ich analiz. Jednym z nich jest moment zakończenia gromadzenia materiału empirycznego, o którym decyduje teoretyczne nasycenie. W artykule podjęto próbę przybliżenia dylematów młodego badacza związanych z nasyceniem teoretycznym. Refleksje zostaną przedstawione na podstawie analizy piśmiennictwa naukowego oraz fragmentu z badań własnych, obejmującego wątpliwości związane z nasyceniem teoretycznym w procedurach metodologii teorii ugruntowanej.

SŁOWA KLUCZOWE: teoretyczne nasycenie, procedury metodologii teorii ugruntowanej, badania terenowe
\end{abstract}

\section{Wprowadzenie}

Pojęcie nienasycenia (niezupełności) często łączone jest z filozofią, logiką, matematyką (zob. Frege, 1977). Kategoria ta ma szerokie znaczenie i wielorakie zastosowanie w różnych dyscyplinach i dziedzinach nauki (por. Łagosz, 1997). W naukach społecznych nienasycenie i nasycenie mają swoje miejsce w obszarze badań jakościowych, a dokładnie w metodologii teorii ugruntowanej (grounded theory), która służy do budowania teorii średniego zasięgu (Konecki, 2000, s. 26). Pierwotnie została opracowana przez Anslema Straussa i Barneya Glasera (1967). Jest to strategia analityczno-badawcza, która obejmuje procedury, zapewniające zbieranie oraz analizę danych empirycznych w sposób ściśle uporządkowany i nieprzypadkowy (Konecki, 200o). Na elementy MTU, które należy traktować spójnie, składają się procedury teore- 
tycznego pobierania próbek (theoretical sampling), kodowania (coding), teoretycznego nasycenia (theoretical saturation) oraz stałej analizy porównawczej (constant comparative method) (Strauss i Corbin, 1990; Strauss i Glaser, 2009; Konecki, 200o). Wszystko to poprzedzone jest założeniem o minimalnej prekonceptualizacji przed rozpoczęciem badań (Strauss i Glaser, 2009; por. Konecki, 2000).

Teoretyczne nasycenie stanowi istotną, metodologiczną procedurę, która rozstrzyga o zakończeniu zbierania danych. Badacz zaprzestaje pobierania kolejnych grup porównawczych, gdy wyłonione kategorie zostaną nasycone. Oznacza to, że nie pojawiają się już żadne nowe dane i występuje powtarzalność przykładów (Strauss i Glaser, 2009; Konecki, 200o). Teoretyczne nasycenie można także określić jako sposób weryfikacji rzetelności organizacji procesu badawczego (zob. Pasikowski, 2015).

Niektórzy autorzy kwestionują teoretyczne nasycenie jako wyraźne kryterium określające zakończenie pobierania danych empirycznych (Bryman, 1988; O’Reilly i Parker, 2013; Rowlands, Wadell i McKenna, 2015; Bowen, 2008, za: Pasikowski, 2015). Sugerują, że może być ono źródłem nadmiernego subiektywizmu. Takie postrzeganie procedury metodologicznej wzbudza wątpliwości, szczególnie u początkujących badaczy. Rodzą się pytania: kiedy wiadomo, że nastąpiło teoretyczne nasycenie kategorii i że można zakończyć proces pobierania materiału empirycznego? Jak mieć pewność, że nie pojawią się nowe kategorie i ich własności przy dalszym zbieraniu danych? Jak poradzić sobie $\mathrm{z}$ taką niepewnością?

Moim celem jest podzielenie się dylematami początkującego badacza, dotyczącymi teoretycznego nasycenia, w kontekście literatury naukowej oraz badań własnych, z udziałem kuratorów sądowych. Podjęta analiza i refleksje są jedynie fragmentem szerszego projektu naukowego' ${ }^{1}$, nad którym prace analityczne są nadal w toku i podlegają modyfikacjom. Celem artykułu nie jest przedstawienie wyników eksploracji terenowej oraz pełnych analiz danych z badań własnych. Zamierzam jedynie przybliżyć wątpliwości związane z teoretycznym nasyceniem, które stanowią źródło dylematów o charakterze metodologicznym. Zwłaszcza dla młodego badacza, który stoi na początku swojej drogi w prowadzeniu eksploracji z zastosowywaniem procedur metodologii teorii ugruntowanej.

1 Badania z udziałem kuratorów sądowych, obejmujące obserwację uczestniczącą terenowej pracy kuratorów. 


\section{Przegląd literatury}

Dokonując analizy piśmiennictwa naukowego w poszukiwaniu istoty teoretycznego nasycenia, będącym jednym z elementów procedur metodologii teorii ugruntowanej, nie sposób byłoby nie zacząć od wyjaśnienia zaproponowanego przez A. Straussa i B. Glasera (2009, s. 53), którzy definiują je jako: „Kryterium oceny, kiedy należy zaprzestać pobierania do próby rozmaitych grup związanych z kategorią". Samo nasycenie autorzy określają jako moment w gromadzeniu materiału empirycznego, w którym:

(...) nie są odnajdywane żadne dodatkowe dane, poprzez które socjolog może rozwinąć własności kategorii. Widząc raz za razem podobne przykłady, badacz staje się empirycznie przeświadczony, że kategoria jest nasycona. Zadaje sobie trud szukania grup, które rozszerzają różnorodność tak dalece, jak to jest możliwe, aby właśnie być pewnym, że nasycenie jest oparte na najszerszym możliwym zakresie danych odnoszących się do kategorii (Strauss i Glaser, 2009, s. 53).

Zatem, nasycenie teoretyczne przesądza o punkcie w procesie zbierania danych, w którym zaprzestaje się ich dalszego gromadzenia, ponieważ każda kolejna obserwacja czy wywiad nie dostarczają nowych własności kategorii. Wtedy badacz przechodzi do kolejnych grup, by nasycić następne kategorie.

Z kolei Krzysztof Konecki, odwołując się również do A. Straussa i B. Glasera (1967), pisze, że:

Teoretyczne nasycenie odbywa się poprzez formułowanie własności kategorii (...). Własności te można skompletować tylko wtedy, gdy pobierzemy różnorodne grupy porównawcze, umożliwiające wykrycie różnorodnych warunków funkcjonowania kategorii (Konecki, 2000, s. 31).

Wynika $\mathrm{z}$ tego, że nasycenie teoretyczne jest bezpośrednio związane z teoretycznym pobieraniem prób, polegającym na zbieraniu kolejnych danych empirycznych. Procedura ta zakłada permanentne porównanie przypadków, co jest niezbędne do rozwijania własności kategorii (Strauss i Glaser, 2009).

Wyżej wymienieni autorzy zwracają szczególną uwagę na potrzebę sięgnięcia po szeroką grupę porównawczą dla rzetelnego opracowania kategorii i jej własności. W celu poszerzenia grup porównawczych metodologia teorii ugruntowanej przewiduje tzw. triangulację, która sprowadza się do stosowania kilku różnych metod, źródeł zbierania danych lub zaangażowania wielu badaczy (por. Denzin, 1978, za: Konecki, 2000; Konecki i Chomczyński, 2012; zob. Chomczyński, 2014). Jest to procedura, dzięki której badacz ma możliwość poznawania rzeczywistości z różnych perspektyw, co zwiększa wiarygodność i obiektywność procesu porównywania przypadków oraz ich analizy 
(Konecki, 2000; Konecki i Chomczyński, 2012). Autorzy opracowań podkreślają wagę różnorodności zbieranych danych. Badacz powinien gromadzić przypadki do siebie podobne, w celu opracowania minimalnych porównań oraz przypadki zasadniczo różniące się od siebie, by ukazać zróżnicowane warunki pojawiających się kategorii (Glaser i Strauss, 2009; Konecki, 2000 s. 30).

W dyskursie naukowym nie brakuje krytyki MTU, ponieważ badacze zarzucają procedurom zbierania i analizy danych w badaniach jakościowych nadmierny subiektywizm i nieprecyzyjność (zob. Bryman, 1988; O’Reilly i Parker, 2013; Rowlands i in., 2015; por. Silverman, 2007). Jednak trzeba pamiętać, że procedury MTU są w pełni kontrolowane, aktywne i celowe (Strauss i Glaser, 2009, s. 61). Oczywiście pod warunkiem, że badacz stosuje się ściśle do procedur metodologicznych. W przeciwnym przypadku wygenerowana przez niego teoria będzie „wątła i niezintegrowana” (Strauss i Glaser, 2009, s. 54). Dlatego ujednolicanie i zarzucanie subiektywizmu badaniom jakościowym jest głęboko powierzchowne i lekceważące. Zwłaszcza, że MTU dysponuje szczegółowymi procedurami gromadzenia i analizy danych empirycznych. Nie można zapominać, że w badaniach ilościowych również wiele zależy od samego badacza.

Nasycenie teoretyczne w badaniach wykorzystujących metodologię teorii ugruntowanej jest uwarunkowane nie tylko rzetelnością stosowanych procedur, ale także celem badań i tym czy próba zawiera odpowiednią liczbę danych, by nasycić kategorię (por. Pasikowski, 2015). Przy teoretycznym pobieraniu prób badacz (zgodnie z założeniami procedur) decyduje jakie dane i u jakich grup zbierać. Z tym, że nie zawsze dociera do danych, które są użyteczne dla generowanej teorii. Zdarza się, że badacz uwikła się w nadmierne zbieranie różnych danych (zob. Kacperczyk, 2016). O „nawyku kompulsywnego gromadzenia materiału" pisała Anna Kacperczyk (2016, s. 675) w pracy Społeczne Światy. Teoria-empiria-metody badań. Na przykładzie społecznego świata wspinaczki. Według badaczki konsekwencją tego nawyku jest rozbieżność pomiędzy zebranym materiałem a tym, który jest potrzebny. Może to doprowadzić do nieładu w projekcie. Badaczka w celu uniknięcia redukcji swoich działań jedynie do czynności zbierania materiału empirycznego porządkowała kody szczegółowe w metazbiory. Czynności te pomogły zapanować nad obszernością materiału (Kacperczyk, 2016, s. 676), a co za tym idzie, dotrzeć do momentu nasycenia kategorii.

Pomocne w porządkowaniu materiału empirycznego są programy do analizy danych jakościowych, które można stosować również przy projektach wykorzystujących procedury metodologii teorii ugruntowanej. Izabela Ślę- 
zak i Jakub Niedbalski (2014) pisali o funkcjach programu NVivo w ramach oprogramowania CAQUDA, wspomagającego analizę danych jakościowych. Funkcje programu obejmują czynność kodowania przez nadanie etykiet zaznaczonemu fragmentowi tekstu (Ślęzak i Niedbalski, 2014). Proces analizy materiału jest znacznie sprawniejszy, a w konsekwencji również identyfikacja momentu teoretycznego nasycenia kategorii. Dla początkujących badaczy taki program może być przydatny, szczególnie przy nagromadzeniu szerokiego zbioru kodów.

Ponadto, do ustalenia przewidywań obszerności próby w projektach badawczych (np. potrzebnych przy konstruowaniu wniosku grantowego na finansowanie badań) można wykorzystać badania dotyczące wielkości próby badawczej, najczęściej stosowane w badaniach jakościowych (Pasikowski, 2014). Jednak nie powinna to być dominująca wskazówka, ponieważ, jak zostało wcześniej podkreślone, przy teoretycznym doborze próby badawczej, wielkość materiału empirycznego zależy od tego, czy wyłonione kategorie zostały nasycone.

Warto także sięgać do dostępnych rozwiązań w literaturze. W piśmiennictwie naukowym oprócz stosowania się do tekstów zwierających wyjaśnienia procesów metodologicznych MTU (zob. Gorzko, 2008; Charmaz, 2009; Strauss i Glaser, 2009; Glaser i Holton, 2010; Konecki, 2000), równie pomocne jest dokładne przestudiowanie warsztatu metodologicznego innych badaczy, którzy korzystali z procedur MTU w swoich projektach (zob. Konecki, 1992; Charmaz, 1997; Gorzko, 2005; Chomczyński, 2008; Dymarczyk, 2008; Licqurish i Seibold, 2011; Szczepanik, 2015; Kacperczyk, 2016; Ślęzak, 2016, Nascimento i in., 2018). Jest wiele prac empirycznych, które przedstawiają takie badania. Analizując literaturę w kontekście samego nasycenia teoretycznego nie doszukałam się licznych tekstów, które ściśle koncentrują się jedynie na problematyce nasycenia kategorii. Jest to zaskakujące, zważywszy na różnorodność i złożoność procedur MTU (zob. Gorzko, 2010, 2013). W pracach empirycznych jest to element procesu badawczego, któremu również nie poświęca się dużo miejsca. Niewątpliwie dla początkującego badacza poszukiwania odpowiedzi na pytania dotyczące teoretycznego nasycenia stanowią wyzwanie.

\section{Dylematy własne dotyczące nasycenia teoretycznego}

Do podjęcia problematyki związanej z nasyceniem teoretycznym przyczyniły się również wątpliwości towarzyszące mi podczas realizacji własnego projektu badawczego. Doświadczenie trudności związanych z zastosowaniem procedur metodologicznych w wybranym kontekście jest nierozłącznym elementem badań. Zwłaszcza gdy jest się początkującym badaczem. 
Badania terenowe (Babbie, 2004, 2013), które posłużyły mi za przykład $\mathrm{w}$ analizie dylematów związanych $\mathrm{z}$ teoretycznym nasyceniem kategorii, dotyczą pracy kuratorów sądowych w terenie. Przyjęłam strategię jakościową, która mieści się w przestrzeni paradygmatu interpretatywnego, w tym interakcjonizmu symbolicznego (Blumer, 2009; Hałas, 2006). Ramy teoretyczne, jakimi się posłużyłam, obejmują założenia koncepcji rytuałów interakcyjnych Ervinga Goffmana (2006). Do gromadzenia i analizy danych empirycznych wykorzystałam procedury metodologii teorii ugruntowanej (Strauss i Corbin, 1990). Techniki badawcze, jakie zastosowałam to obserwacja uczestnicząca jawna. Dodatkową techniką gromadzenia danych były wywiady (Silverman, 2007, zob. Ślęzak, 2016) prowadzone z kuratorami podczas i (jeśli była potrzeba uzupełnienia materiału empirycznego) na zakończenie obserwacji.

Towarzyszenie kuratorom podczas ich pracy trwało kilka miesięcy, co $\mathrm{w}$ rezultacie przyniosło obszerny i wnikliwy materiał empiryczny. Zbieranie materiału, porządkowanie go oraz analiza pochłaniały dużo czasu. W rezultacie dotarłam do momentu, w którym zgromadziłam obszerny zakres danych z obserwacji, z których wyłaniałam kolejne kategorie. Nietrudno było uwikłać się w nadmierne gromadzenie materiału. Doświadczyłam podobnego dylematu, o którym pisze A. Kacperczyk (2016). Zatem, by zapobiec wkradającemu się nieładowi w danych empirycznych stale pracowałam nad jego uporządkowaniem. Notatki z obserwacji tworzyłam w ramach przygotowanej na potrzeby badań karty obserwacji, odpowiednio ponumerowanej i zatytułowanej. Dzięki temu proces kodowania przebiega znacznie sprawniej. Niemniej, ze względu na obszerność materiału czynności te stanowią czasochłonny element procesu badawczego. Kolejno, kody nazywałam, numerowałam zgodnie z procedurą. Kategorie pomocniczo opracowywałam w graficznych schematach, ponieważ ułatwiało mi to określenie powiązań między kategoriami (por. Gorzko, 2005; Ślęzak, 2016). Porządkowanie materiału usprawniło opisywanie kategorii centralnych oraz ich charakteru interakcyjnego (zob. Konecki, 2000, s. 48; por. Chomczyński, 2008). Nieprzypadkowe i celowe stosowanie procedur wybranej metodologii z pewnością pomaga zidentyfikować moment nasycenia kategorii.

Inny dylemat dotyczył opracowywania kategorii na podstawie danych empirycznych, co także jest związane z ich nasyceniem. Do rozwiązania moich wątpliwości przyczyniły się założenia Kathy Charmaz (2009), mówiące o tym, że każdy badacz zbiera dane w inny sposób. Nawet jeżeli wykorzystuje te same techniki badawcze i przyjmuje tożsamy przedmiot badań, to inaczej dostrzega zjawiska, które obserwuje i odmiennie je interpretuje. Ponadto równie ważna jest, przyjęta przeze mnie perspektywa interakcjonizmu sym- 
bolicznego, która zakłada, że znaczenia nadawane przez uczestników sytuacji społecznych są względne, zmienne i kontekstowe (Blumer, 2009; Hałas, 2006). Przyjęłam, że badania, które realizuję mogą zostać pogłębione lub zinterpretowane w odmienny sposób. Co za tym idzie, kategorie, ich własności i hipotezy również mogą być inne.

Pomimo tego, że pewne etapy procesu badawczego mam już za sobą, to w dalszym ciągu studiuję poszczególne elementy procedur metodologicznych. Jednak moment badań, w którym się znajduję, pozwolił mi na wskazanie dylematów, z jakimi musiałam się mierzyć w kontekście teoretycznego nasycenia. Co nie znaczy, że jeszcze nie spotkam się z innymi barierami $\mathrm{w}$ przebiegu dalszych analiz i interpretacji.

\section{Podsumowanie}

Inspirację do przedstawienia moich refleksji stanowił przegląd literatury w kontekście teoretycznego nasycenia oraz własne trudności w prowadzeniu badań. Pragnę podkreślić, że proces analizy danych empirycznych mojego projektu badawczego nie jest jeszcze zakończony. Prace nadal trwają, dlatego nie mogłam przedstawić pełnych wniosków z prac analitycznych w niniejszym artykule. Natomiast, jak napisałam wcześniej, nie było to moim celem.

Literatura naukowa wyjaśniająca poszczególne elementy procesu badawczego jest pomocna dla początkujących badaczy (zob. Gorzko, 2008; Charmaz, 2009; Strauss i Glaser, 2009; Glaser i Holton, 2010; Konecki, 2000). Wyjaśnień dostarczają również liczne opracowania empiryczne, które ukazują warsztat metodologiczny projektu badawczego razem z jego wadami i dylematami (zob. Konecki, 1992; Charmaz, 1997; Gorzko, 2005; Chomczyński, 2008; Dymarczyk, 2008; Licqurish i Seibold, 2011; Szczepanik, 2015; Kacperczyk, 2016; Ślęzak, 2016; Nascimento i in., 2018). W tekstach empirycznych autorzy przeważnie piszą czym nasycenie teoretyczne $w$ istocie jest, ale nie stanowi to dominującej część fragmentów, dotyczących metodologii prowadzonych badań (zob. Chomczyński, 2008; Szczepanik, 2015). Natomiast, niezwykle pomocne jest, gdy doświadczeni badacze piszą o swoich wątpliwościach i ich rozstrzygnięciach (zob. Chomczyński, 2014; Szczepanik, 2015; Kacperczyk, 2016; Ślęzak, 2016). Z uwagi na specyfikę badań w podejściu jakościowym, nie zawsze można skorzystać z tych rozwiązań, ale dostarczają one przydatnych wskazówek. Można również kierować się badaniami dotyczącymi ilości przewidywanego materiału empirycznego (zob. Pasikowski, 2014). Użyteczne jest także wspomaganie się programami do analizy danych jakościowych (zob. Ślęzak i Niedbalski, 2014). Jednak warto mieć na uwadze, że badania zasadniczo różnią się od siebie, pod względem przedmiotów, problemów badawczych, 
wykorzystywanej metodologii, ram teoretycznych, reprezentatywności zebranych danych, a także osób, które to badanie realizują.

Ścisłe trzymanie się procedur wskazanych przez wybraną metodologię zapewnia staranność doboru grup porównawczych, jakość zebranych danych oraz opracowanych hipotez. Jest to wręcz etyczny obowiązek badaczy do rzetelnej realizacji projektu, tak by wnosił wartościową wiedzę naukową. Wreszcie ważne jest założenie od samego początku badań, że nasze wnioski nie są ostateczne, definitywne i nieodwołalne. Zawsze pozostaje możliwość, by kontynuować badania w nowym projekcie.

\section{BIBLIOGRAFIA}

Babbie, E. (2004). Badania społeczne w praktyce. Warszawa: Wydawnictwo Naukowe PWN.

Babbie, E. (2013). Podstawy badań jakościowych. Warszawa: Wydawnictwo Naukowe PWN.

Blumer, H. (2009). Interakcjonizm symboliczny. Perspektywa i metoda. Kraków: Zakład Wydawniczy Nomos.

Bowen, G. (2008). Naturalistic inquiry and the saturation concept: a research note. Qualitative Research, nr 8(1), 137-142.

Bryman, A. (1988). Quantity and quality in social research. New York: Taylor \& Francis Group.

Charmaz, K. (1997). Good Days, Bad Days: The Self in Chronic Illness and Time. New Brunswick: Rutgers University Press.

Charmaz, K. (2009). Teoria ugruntowana praktyczny przewodnik po analizie jakościowej. Warszawa: Wydawnictwo Naukowe PWN.

Chomczyński, P. (2008). Mobbing w pracy z perspektywy interakcyjnej. Proces stawania się ofiarą. Łódź: Wydawnictwo Uniwersytetu Łódzkiego.

Chomczyński, P. (2014). Działania wychowanków schronisk dla nieletnich i zakładów poprawczych. Łódź: Wydawnictwo Uniwersytetu Łódzkiego.

Dymarczyk, W. (2008). Temporalny wymiar karier menedżerskich. Katowice: „Śląsk” Wydawnictwo Naukowe.

Glaser, B. i Holton, J. (2010). Remodelowanie teorii ugruntowanej. Przegląd Socjologii Jakościowej, t. VI, nr 2, 81-102.

Goffman, E. (2006). Rytuat interakcyjny. Warszawa: Wydawnictwo Naukowe PWN.

Gorzko, M. (2005). „Rodzinna Atmosfera” i „Uprzejma Obsługa”. W stronę substantywnej teorii obsługi ruchu turystycznego - komunikat z badań. Przegląd Socjologii Jakościowej, t. I, nr 1, 4-19.

Gorzko, M. (2008). Procedury i emergencja: o metodologii klasycznych odmian teorii ugruntowanej. Szczecin: Wydawnictwo Naukowe Uniwersytetu Szczecińskiego.

Gorzko, M. (2010). „Drugie pokolenie” teoretyków grounded theory. Zeszyty Naukowe Uniwersytetu Szczecińskiego. Studia Sociologica, nr 20, 27-43.

Gorzko, M. (2013). Teoria ugruntowana jako „rodzina metod”? Opuscula Sociologica, nr 4(6), 5-16.

Hałas, E. (2006). Interakcjonizm symboliczny. Społeczny kontekst znaczeń. Warszawa: Wydawnictwo Naukowe PWN.

Frege, G. (1977). Pisma semantyczne. Warszawa: Wydawnictwo Naukowe PWN.

Kacperczyk, A. (2016). Społeczne Światy. Teoria-empiria-metody badań. Na przykładzie społecznego świata wspinaczki. Łódź: Wydawnictwo Uniwersytetu Łódzkiego.

Konecki, K. (1992). Nowi pracownicy a kultura organizacyjna - studium folkloru fabrycznego. Łódź: Wydawnictwo Uniwersytetu Łódzkiego. 
Konecki, K. (2000). Studia z metodologii badań jakościowych. Teoria ugruntowana. Warszawa: Wydawnictwo Naukowe PWN.

Konecki, K. i Chomczyński, P. (2012). Słownik socjologii jakościowej. Warszawa: Difin.

Licqurish, S. i Seibold, C. (2011). Applying a contemporary grounded theory methodology. Nurse Researcher, nr 18(4), 11-16.

Łagosz, M. (1997). Analiza Fregowskiej kategorii nienasycenia. Filozofia Nauki, nr 3(19), 55-70.

Nascimento, L.C.N., Souza, T.V., Oliveira, I.C.S., Moraes, J.R.M.M., Aguiar, R.C.B. i Silva, L.F. (2018). Theoretical saturation in qualitative research: an experience report in interview with schoolchildren. Rev Bras Enferm, nr 71(1), 228-3.

O’Reilly, M. i Parker, N. (2013). 'Unsatisfactory Saturation': a critical exploration of the notion of saturated sample sizes in qualitative research. Qualitative Research, $\mathrm{nr}$ 13(2), 190-197.

Pasikowski, S. (2014). Kultura metodologiczna i raportowanie badań empirycznych publikowanych w wiodących czasopismach poświęconych zagadnieniom edukacji. Kultura i Edukacja, nr 2, 103-133.

Pasikowski, S. (2015). Granice teoretycznego nasycenia. Rocznik Lubuski, t. 41, nr 1, 34-40.

Rowlands, T., Wadell, N. i McKenna, B. (2015). Are We There Yet? A Technique to Determine Theoretical Saturation. Journal of Computer Information System, nr 56(1), 40-47.

Silverman, D. (2007). Interpretacja danych jakościowych. Warszawa: Wydawnictwo Naukowe PWN.

Strauss, A. i Corbin, J. (1990). Basics of qualitative research: Grounded theory procedures and techniques. London: Sage Publications.

Strauss, A.i Glaser, B. (2009). Odkrywanie teorii ugruntowanej. Kraków: Zakład Wydawniczy Nomos.

Szczepanik, R. (2015). Stawanie się recydywistą. Kariery instytucjonalne osób powracających do przestępczości. Łódź: Wydawnictwo Uniwersytetu Łódzkiego.

Ślęzak, I. (2016). Praca kobiet świadczacych usługi seksualne w agencjach towarzyskich. Łódź: Wydawnictwo Uniwersytetu Łódzkiego.

Ślęzak, I. i Niedbalski, J. (2014). Główne funkcje programu NVivo a procedury metodologii teorii ugruntowanej, czyli jak realizować badanie oparte na MTU, korzystając z oprogramowania CAQDA?. W: J. Niedbalski (red.), Metody i techniki odkrywania wiedzy narzedzia CAQDA w procesie analizy danych jakościowych. Łódź: Wydawnictwo Uniwersytetu Łódzkiego.

\section{SUMMARY}

\section{Theoretical Saturation in Research Using Grounded Theory Methodology Procedures - from the Experience of a Young Researcher}

In the area of qualitatively oriented research, the concept of saturation is closely related to the methodology of grounded theory. The methodological procedures include the theoretical saturation of the categories. It is the main criterion which signals the end of collecting the comparative groups (Konecki, 200o). The grounded theory methodology provides clear instructions, but during conduct research, many dilemmas arise in the way of collecting empirical data and their analysis. One of them is the end of the collection of empirical material, which is determined by theoretical saturation. This article is an attempt to present the dilemmas of a young researcher related to theoretical saturation. The reflections will be presented on the basis of an analysis of the scientific literature and a fragment of own research, including doubts related to theoretical saturation in the procedures of the grounded theory methodology.

KEYWORDS: theoretical saturation, grounded theory methodology procedures, field research 